\title{
GM-NAINO: Global Mutation based Novel Artificial Immune Network Optimization for Enhancing Data Security in Public Cloud Storage System
}

Priyadharshini Kaliyamoorthy ( $\sim$ priyadharshinik355@gmail.com )

Sathyabama Institute of Science and Technology

Aroul Canessane Ramalingam

Sathyabama Institute of Science and Technology

Keywords:

Posted Date: July 9th, 2021

DOI: https://doi.org/10.21203/rs.3.rs-379571/v1

License: (c) (1) This work is licensed under a Creative Commons Attribution 4.0 International License.

Read Full License 


\section{Abstract}

The authors have requested that this preprint be removed from Research Square. 